\title{
Dental discriminant sexing of human cremated remains
}

\author{
Maria Kaczmarek, Janusz Piontek, Andrzej Malinowski
}

In this paper set of discriminant functions, based on mesiodistal and buccolingual diameters of teeth crowns is presented. It is possible to use them in assessing sex of immature individuals from cremated graves.

\section{Introduction}

Studying human skeletal remains anthropologists are often faced with difficulties of sexual diagnosis of unknown individuals. In order to avoid them, improvements in various techniques for sexual diagnosis of human skeletal remains have been made recently. Special attention has been paid to the dentition as one of the criteria for sexing immature skeletons. Sexual dimorphism of the dentition has been prooved by a number of investigators who claimed that males and females teeth sizes are different [GARN et al. 1964, RosENZWEIG 1970, POTTER 1972, BIgGERSTAFF 1975, PERZIGIAN 1976, RöSING 1983]. However the range of this phenomenon is not quite clear.

It is well known that teeth are the most valuable parts of the skeleton for paleontologic studies. It holds true for

Zaklad Antropologii UAM ul. Fredry 10, 61-701 Poznań following reasons:

- their indestructibility under fossil conditions,

- their development under strong genetic control in early stages of ontogeny (much earlier than any other part of skeleton),

- their relative freedom from the impact of postnatal enviropment.

With regard to the cremation graves, teeth, and as a matter of fact the nonerupted calcified crowns of permanent teeth, are the only parts of skeleton where morphological structures are well preserved under cremation. Detailed analysis of human cremated remains indicates some new possibilities for morphological observations [KACZMAREK 1981] (Fig. 1).

These facts prompted the authors to the discussion whether two basic tooth crown diameters - mesiodistal and buccolingual - could be applied for sexing subadults from cremated graves.

The main purpose of the article then is to provide dental discriminant 

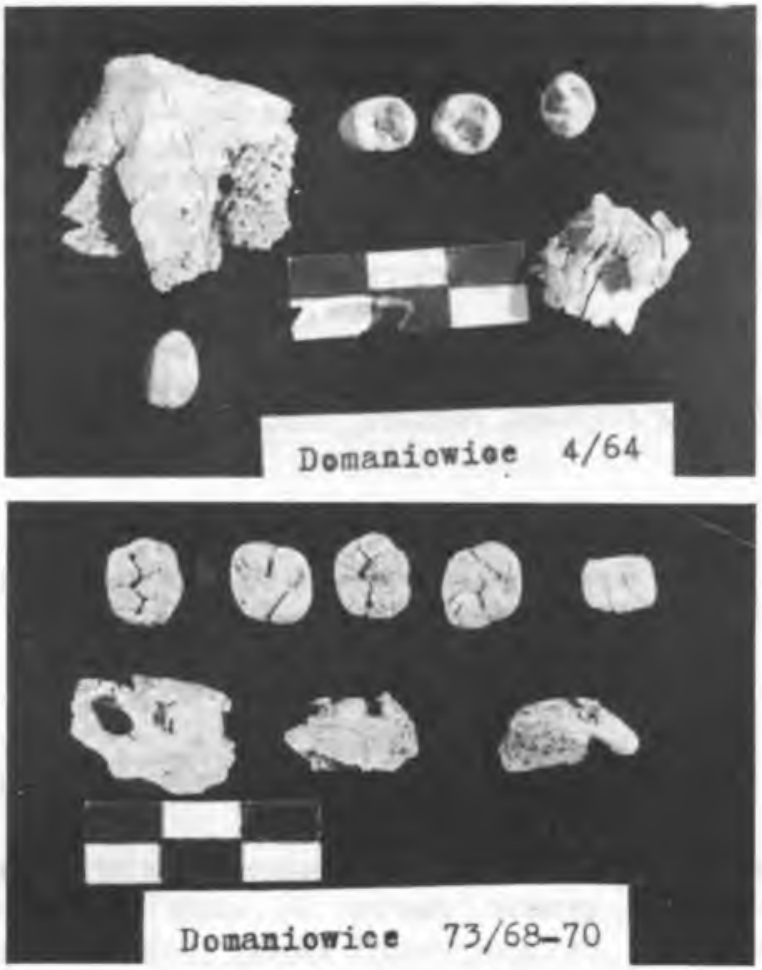

Fig. 1. Human skeletal remains from cremated grave. Crowns of non-erupted permanent teeth in the upper row of the picture

functions developed using two tooth crown diameters - mesiodistal and buccolingual. These functions provide an additional method for sexing children remains from cremated graves.

\section{Materials and methods}

Materials for our purpose were collected in the Department of Orthodontics of the Medical Academy in Poznan. From the sample of 194 dental casts of individuals of known sex, only 138 possessing complete permanent dentition without any demages were selected for further investigations. Using this subsample of 138 individuals with complete sets of measurements insured that sample size would be constant in all statistic analyses. Thus, the reference sample for calculation of the discriminant functions was comprised of 69 boys and 69 girls.

The measurements of tooth crown were taken with vernier caliper and with accuracy to $0.01 \mathrm{~mm}$. Two measurements were taken on all permanent teeth (except for M3) on both sides of the jaws: mesiodistal $\left(\mathrm{M}-\mathrm{D}_{\text {cor }}\right)$ and buccolingual (B- $\left.\mathrm{L}_{\text {cor }}\right)$. Measurements techniques are illustrated in Figure 2.

Mesiodistal diameter (M- $D_{\text {cor }}$ ) was taken as the dimension between the adjacent contact points located at the mesial and distal crest of curvature of occlusal surface (upper row on the scheme).

A
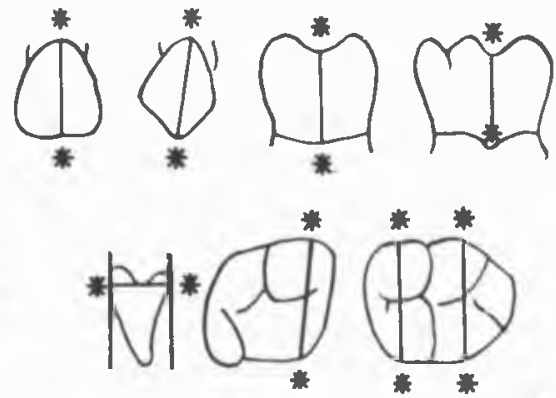

Fig. 2. Measurements points for: mesiodistal diameter (M-D $\mathbf{D}_{\text {cor }}$ ) - upper row, and buccolingual diameter (B - $\mathrm{L}_{\text {cor }}$ ) - lower row

Buccolingual diameter (B- $\left.\mathrm{L}_{\text {cor }}\right)$ was measured as the dimension taken perpendicularly to the plane of occlusal 
surface (at right angle to the $\mathrm{M}-\mathrm{D}_{\text {cor }}$ ) with end points located at the crown midpoint. Canine measurements were taken on the root below the cemento-enamel junction. Whereas those of lower molars were measured twice - between the end points on protoconid-metaconid and hypoconidentoconid, then averaged.

The measurements from both sides of jaw of each individual were averaged. Then, the resulting values were examined for sex differences with univariate analysis. The differences between the male and female means for each measurement were tested with Student's $t$ test. Percentage sexual dimorphism was also calculated for each measurement as:

$$
\frac{\text { male mean }}{\text { female mean }}-1 \cdot 100 \% \text {. }
$$

Results of univariate analysis enabled to exclude from further examinations teeth of small degree of sexual dimorphism.

Then, Anderson's linear discriminant functions were used in the decision model which is being applied to the case of sex identification [ANDERSON 1958]. Va riables for separate tooth and sets of teeth were incorporated to the discriminant functions.

\section{Results and discussion}

The arithmetic means of tooth diameters are presented in Table 1. As it is seen teeth of boys tend to be larger than those of girls in all $M-D_{\text {cor }}$ diameters, whereas in $\mathrm{B}-\mathrm{L}_{\text {cor }}$ diameters in several instances $\left(\mathrm{I}^{1}, \mathrm{I}^{2}, \mathrm{P}^{2}, \mathrm{I}_{1}, \mathrm{I}_{2}\right)$ are slightly smaller. It supports Garn's conclusion that mesiodistal diameter much better discriminates sexes than buccolinqual. [GARN et al. 1966, 1967]. However, these results are contrary to those of RósING, [1983] who claimed that the male means of both $\mathrm{M}-\mathrm{D}_{\text {cor }}$ and $\mathrm{B}-\mathrm{L}_{\text {cor }}$ exceeded female for all permanent teeth (M2 and M3 were excluded).

Table 1. Means of tooth measurements (in $\mathrm{mm}$ )

\begin{tabular}{|c|c|c|c|c|c|}
\hline \multirow{2}{*}{$\begin{array}{l}\text { Tooth } \\
\text { Diameter }\end{array}$} & \multicolumn{2}{|c|}{ Males } & \multicolumn{2}{|c|}{ Females } & \multirow[t]{2}{*}{$t$} \\
\hline & $\bar{x}$ & s.d & $\bar{x}$ & s.d & \\
\hline $\mathbf{I}^{1} \mathrm{M}-\mathrm{D}$ & 8.68 & 0.56 & 8.40 & 0.69 & $2.65^{* *}$ \\
\hline B-L & 7.07 & 0.65 & 7.09 & 0.59 & 0.13 \\
\hline$I^{2} \mathrm{M}-\mathrm{D}$ & 6.96 & 0.66 & 6.57 & 0.62 & $3.57^{* *}$ \\
\hline B-1 & 6.27 & 0.60 & 6.28 & 0.55 & 0.10 \\
\hline $\bar{C} \mathbf{M} \cdot \mathbf{D}$ & 8.03 & 0.49 & 7.57 & 0.57 & $5.10^{* *}$ \\
\hline B-L & 8.06 & 0.68 & 7.79 & 0.60 & $4.27^{* *}$ \\
\hline $\mathrm{P}^{1} \mathbf{M}-\mathrm{D}$ & 7.23 & 0.64 & 6.95 & 0.70 & $2.39^{* *}$ \\
\hline B-L & 9.20 & 0.72 & 9.01 & 0.72 & 1.53 \\
\hline $\mathbf{P}^{2} \mathbf{M}-\mathrm{D}$ & 6.87 & 0.56 & 6.78 & 0.53 & 0.89 \\
\hline B-L & 9.21 & 0.78 & 9.23 & 0.65 & 0.18 \\
\hline$M^{1} M-D$ & 11.02 & 0.66 & 10.50 & 0.69 & $4.48^{n *}$ \\
\hline B-L & 11.24 & 0.64 & 10.80 & 0.59 & $4.16 *$ \\
\hline $\mathrm{M}^{2} \mathrm{M}-\mathrm{D}$ & 10.55 & 0.77 & 10.00 & 0.68 & $4.39^{*}$ \\
\hline B-L & 11.15 & 0.57 & 10.66 & 0.80 & $4.11^{* *}$ \\
\hline $\mathrm{I}_{1} \mathrm{M}-\mathrm{D}$ & 5.45 & 0.36 & 5.31 & 0.45 & $2.02^{*}$ \\
\hline B-L & 5.86 & 0.46 & 5.90 & 0.44 & 0.41 \\
\hline$I_{2} M-D$ & 5.96 & 0.42 & 5.75 & 0.44 & $2.85^{* *}$ \\
\hline B-L & 6.03 & 0.50 & 6.14 & 0.43 & 1.39 \\
\hline C $M-D$ & 7.13 & 0.51 & 6.52 & 0.49 & $7.02 * *$ \\
\hline B-L & 7.30 & 0.71 & 7.18 & 0.56 & 1.04 \\
\hline$P_{1} M-D$ & 7.25 & 0.61 & 7.09 & 0.49 & 1.66 \\
\hline B-L & 7.92 & 0.61 & 7.75 & 0.60 & 1.06 \\
\hline $\mathrm{P}_{2} \mathrm{M}-\mathrm{D}$ & 7.42 & 0.58 & 7.16 & 0.64 & 2.56 \\
\hline B-L & 8.37 & 0.60 & 8.27 & 0.62 & 1.04 \\
\hline $\mathbf{M}_{1} \mathbf{M}-\mathrm{D}$ & 11.55 & 0.69 & 10.82 & 0.76 & $5.87^{* *}$ \\
\hline B-L & 10.74 & 0.57 & 10.24 & 0.61 & $4.90^{* *}$ \\
\hline $\mathrm{M}_{2} \mathrm{M}-\mathrm{D}$ & 11.02 & 0.75 & 10.45 & 0.65 & $4.75^{* *}$ \\
\hline B-L & 10.46 & 0.66 & 10.08 & 0.56 & $3.62^{* *}$ \\
\hline
\end{tabular}

- Sex differences significant at 0.05 level

* Sex differences significant at 0.01 level 
Student's $t$ test showed that the means of majority of variables are significantly dimorphic at the 0.01 level. The male means significantly exceed those of female in the $M-D_{\text {cor }}$ of all teeth except for upper second premolar and two lower premolars. Differences in buccolingual diameter are not always significant.

Percentage sexual dimorphism between the male and female means indicates very similar pattern to those obtained by others [LUNDSTRÖM 1977, GARN et al. 1964, RösING 1983] (Figure 3). The tooth emphasized here is canine. It reflects relatively larger sexual dimorphism and greater sex-discriminatory effectiveness as compared with other teeth. The same is noticed by GARN [1967a, 1966a] and PERZIGIan [1976]. Large sexual dimorphism is also found for all molars, moderate for incisors. Whereas mandibular premolars discriminate sexes to a smaller degree than other teeth. The pattern of percentage sexual dimorphism indicates the canine "field" which is evident for maxillary teeth does not hold true for mandibular teeth in examined material.

Discriminant functions calculated for single tooth and sets of teeth are presented in Table 2. Calculated formulas provide an objective method for sexing skeletal remains from cremated graves. In order to apply them to individual of unknown sex, appropriate measurements $\left(\mathrm{M}-\mathrm{D}_{\mathrm{cor}}\right)$ and $\left.\mathrm{B}-\mathrm{L}_{\mathrm{cor}}\right)$ should be multiplied by corresponding coefficients, then summed to obtain the discriminant score $Y$, which value is compared to the sectioning point. Sex is identified as male if $\mathrm{Y}$ is smaller than 0 and female if $\mathrm{Y}$ is greater than 0 .

\section{SCXUAL OIMORPAISM}

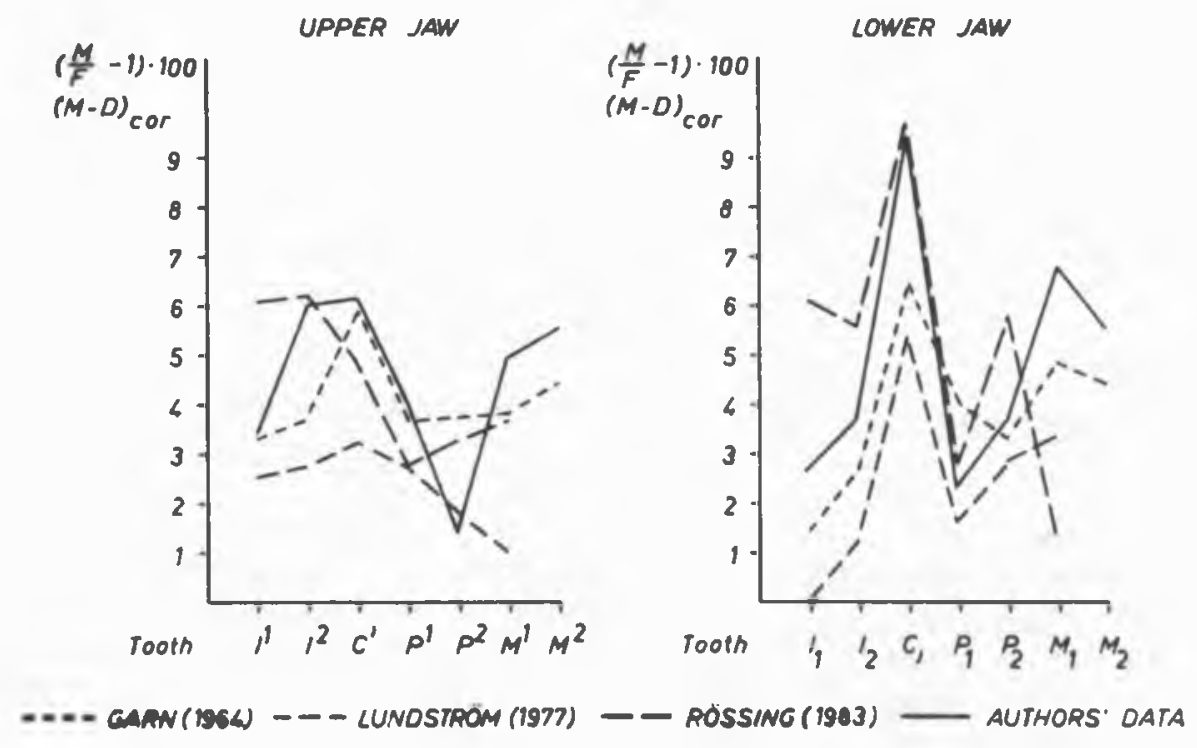

Fig. 3. Percentage sexual dimorphism of mesiodistal diameter for permanent tooth crowns 


\begin{tabular}{|c|c|}
\hline Tooth & Discriminant functions \\
\hline 了' & $Y=-0.81619(M-D)+0.30474(B-L)+4.81630$ \\
\hline$C^{\prime}$ & $Y=-1.71002(M-D)+0.13393(B-L)+12.28088$ \\
\hline$M^{\prime}$ & $Y=-1.05568(M-D)-1.10461(B-L)+23.94995$ \\
\hline$M^{2}$ & $Y=-0.55695(M-D)-1.68996(B-L)+24.44493$ \\
\hline$J_{1}$ & $Y=-0.95984(M-D)+0.39615(B-L)+2.83793$ \\
\hline C, & $Y=-2.54639(M-D)+0.63437(B-L)+1281162$ \\
\hline$M_{1}$ & $Y=-1.06161(M-D)-0.73685(B-L)+19.60895$ \\
\hline$M_{2}$ & $Y=-0.75598(M-D)-0.35887(B-L)+1181948$ \\
\hline Tooth & Discriminant functions \\
\hline$J^{9}+C^{\prime}$ & $\begin{aligned} Y= & -0.20230\left(M-D_{J^{\prime}}\right)+0.59150\left(B-L_{J^{\prime}}\right)-1.66698\left(M-D_{C^{\prime}}\right) \\
& -0.08510\left(B-L_{C^{\prime}}\right)+11.21882\end{aligned}$ \\
\hline $\mathrm{J}_{1}+\mathrm{C}_{1}$ & $\begin{aligned} Y= & +1.00499\left(\mathrm{M}-\mathrm{D}_{J_{1}}\right)+0.40376\left(8-L_{J_{1}}\right)-300695\left(\mathrm{M}-\mathrm{D}_{\mathrm{C}_{3}}\right) \\
& +0.49283\left(\mathrm{~B}-\mathrm{L}_{\mathrm{C}_{j}}\right)+9.19719\end{aligned}$ \\
\hline$M^{\prime}+M^{2}$ & $\begin{aligned} Y= & -0.59415\left(M-D_{M^{1}}\right)-0.60565\left(B-L_{M^{1}}\right)-0.01096\left(M-D_{M^{2}}\right) \\
& -1.35606\left(B-L_{M^{2}}\right)+28.69698\end{aligned}$ \\
\hline$M_{1}+M_{2}$ & $\begin{aligned} Y= & -1.02225\left(\mathrm{M}-\mathrm{D}_{\mathrm{M}_{1}}\right)-0.90369\left(\mathrm{~B}-\mathrm{L}_{\mathrm{M}_{1}}\right)=0.32954\left(\mathrm{M}-\mathrm{O}_{\mathrm{M}_{2}}\right) \\
& +0.49727\left(\mathrm{~B}-\mathrm{L}_{\mathrm{M}_{2}}\right)+19.35632\end{aligned}$ \\
\hline
\end{tabular}

Tabele 2. Dhariminant function of tooth measurements

\section{Literature}

ANDERSON T. W., 1958, An Introduction to Multivariate Statistical Analysis, New York.

BIGGERSTAFF R. H., 1975, Cusp size, sexual dimorphism and heritability of cusp size in twins, Am. J. Phys. Antbrop. 42, 127-139.

GARN S. M., A. B. LEWIS, R. S. KEREWSKY, 1964, Sex differences in tooth size, Y. Phys. Antrop., 12, 125. 126.

GARN S. M., A. B. LEWIS, R. S. KEREWSKY, 1966, Sexual dimorphism in the buccolingual tooth diameter, J. Dent. Res., 43, 1819.

GARN S. M., R. S. KEREWSKY, D. R. SWINDLER, 1966a, Canine "field" in sexual dimorphism of tooth size, Nature, 212, 1501-1502.

GARN S. M., A. B. LEWIS, R. S. KEREWSKY, 1967, Sex differences in roorh shape, J. Dent. Res., 46, 1470.

GARN S. M., A. B. LEWIS, D. R. SWINDLER, R. S. KEREWSKY, 1967a, Genetic control of sexual dimorphism in tooth size, J. Dent. Res., 46, 963-972.
KACZMAREK M., 1981, Analiza odontoskopijna przepalonych szczqtków ludzkich, Przegl. Antrop., 47, 263-271.

LUNDSTRÖM A., 1977, Dental genetics [in:] Orofacial growth and development, ed. by A. A. Dahlberg and Th. M. Graber, Mouton Publishers 91-107.

PERZIGLAN A. J., 1976, The dentition of the Indian Knoll skeletal population: odontometrics and cusp number, Am. J. Phys. Anthrop., 44, 113-122.

POTTER R. H. Y., 1972, Univariate versus multivariate differences in tooth size according to sex, J. Dent. Res., 51, 716-722.

ROSENZWEIG K, 1970, Tooth form as a distinguishing trait between sexes and human populations, J. Dent. Res., 49, $1423-1426$.

ROSING F. W., 1983, Sexing Immarure skeletons, J. Hum. Evol., 12, 149-155.

Maszynopis nadeslano w maju $1986 \mathrm{r}$. 
ZASTOSOWANIE ZĘBOWYCH FUNKCJI DYSKRYMINACYJNYCH DO BADAŃ PRZEPALONYCH SZCZATKOWW KOSTNYCH. Badając ludzkie szczątki kostne antropolog staje często przed problemem określenia płci nieznanego osobnika. Dzięki specyficznym właściwościom uzębienia (struktury zębơw powstają pod ścisłą kontrolą genetyczną, ponadto są oporne na czynniki fosylizacyjne) moze być ono wykorzystane do identyfikacji płci osobników mlodocianych (7-14 lat) z grobów ciałopalnych. Proponuje sį̨ szereg funkcji dyskryminacyjnych bazujących na podstawowych pomiarach zębów (M-D $\mathrm{D}_{\text {cor }}$ i $\left.\mathrm{B}-\mathrm{L}_{\mathrm{cor}}\right)$ pozwalających określać płeć z prawdopodobnieństwem 70-80\%. 